\title{
THE ROLE OF BANK CREDIT AS A DETERMINANT OF ECONOMIC GROWTH IN INDIA
}

\author{
* Prof. Dhiren Jotwani
}

\begin{abstract}
The dynamics of the growth process in any country are varied and diverse. The factors that cause growth, and the processes behind growth itself, have been a very important subject in macroeconomic theory, as well as business studies. Theory has managed to identify certain key factors, of which finance is very important. In recent years, there have been studies using econometric time-series analysis to study the short-run and long-run relationships between finance and growth, for various countries. This paper studies the Indian economy to determine the causal relationship between bank credit and economic growth, using data from 1972 to 2012. The results suggest that provision of bank credit leads to economic growth. However, an increase in economic growth may not lead to further provision of bank credit in the economy. In other words, there is unidirectional causality from bank credit to growth.
\end{abstract}

Keywords: Economic growth, Causality, Time-series analysis, Bank credit

\section{INTRODUCTION}

A crucial question in Economics is: what causes growth? To put it in other words, what are the factors, economic and non-economic, that contribute to a rise in a country's real GDP? Based on this question, we may proceed to state that there are various factors that lead to economic growth. Many of these factors may be non-economic in nature as well. Further, when we measure growth, we are concerned with the real GDP growth, adjusted for inflation and for changes in base years.

The question of economic growth has a direct implication on business administration and business policy. Over the years, scholars have used various approaches, from discussions to complex mathematics, to study this phenomenon. The key factors are those that lead to capital accumulation and technological progress. Human capital and physical capital are essential in the process - which depends on investments - and investments are dependent on finance. Thus, finance is crucial for capital accumulation and technological process.

In India, the financial sector is very large and widespread, comprising of various entities. However, the main sources of finance for corporations are still banks and stock markets. Further, for regular and immediate needs of corporations, banks are very often the preferred means of raising finance. Hence, a study of how

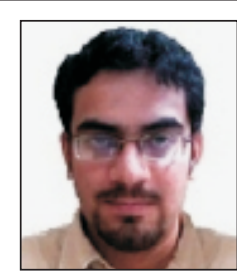

\section{*Prof. Dhiren Jotwani}

Plot $86 / 2$, Sector 8 ,

Gandhinagar - 382007 (GUJARAT)

Email : dhirenjotwani@hotmail.com

Mob : 9376147902 
bank credit determines overall growth in the economy is quite interesting. In recent years, there have been studies using econometric time-series analysis to study the short-run and long-run relationships between finance and growth, for various countries. This paper studies the Indian economy to determine the causal relationship between bank credit and economic growth, using data from 1972 to 2012. The results suggest that provision of bank credit leads to economic growth. However, an increase in economic growth may not lead to further provision of bank credit in the economy. In other words, there is unidirectional causality from bank credit to growth.

\section{Literature Review}

In the earliest studies, only descriptive and narrative analyses were made. However, these early studies form the basis of much of current understanding. Great economists like Bagehot, Schumpeter, McKinnon, Shaw, among others, have written on the role of finance in growth. The topic is too important to be taken lightly. The exact mechanism of understanding the process requires an understanding of growth theory.

Over the years, new theories of economic growth were developed. The most recent theory of endogenous growth very appropriately blends the concept of financial development with economic growth. The prominent initial contributions in this area were by Greenwood and Jovanovic (1990), Pagano (1993) and King and Levine (1993). Their research shows that financial development does have a positive impact on economic growth through investment, saving, productivity of capital and effective management of information.

Further, there is no particular differentiation needed between the proportion of banks or stock markets in the economy. Although this argument still goes on, it is believed that both banks and stock markets behave as complementary, rather than rivals in the finance-growth nexus. This is shown by Boyd and Prescott (1986), Boyd and Smith (1998) and Blackburn and Capasso (2005).

The techniques used for econometric analysis have also evolved over the years. From basic descriptive analyses, to cross sectional studies, the focus has now gradually shifted to multivariate models. In recent years, researchers have used techniques of time-series analysis. The most prominent ones are Jung (1986), Demetriades and Hussein (1996), Neusser and Kugler (1998), Bell and Rousseau (2001), Rousseau and Sylla (2005), among others.

Among earlier and recent work in the Indian context, some important ones are Acharya et al (2009), Bell and Rousseau (2001), Chakraborty (2007, 2010, 2011), Demetriades and Luintel (1996) and Pradhan (2009, 2010a, 2010b, 2011).

\section{Econometric Technique and Results}

It is important in the finance-growth nexus to try and analyze the extent and nature of causality between the two. There are debates over the issue of causality, which can be examined by certain econometric techniques. The data used in this study is time-series data, from 1972 to 2012. It has been collected from the extensive database of the Reserve Bank of India. All the data has been converted to real terms, and natural log values have been used for analysis.

Many current studies have employed cointegration and granger causality tests. Timeseries analysis of data requires various diagnostic checks. For non time-series data, we can directly proceed to our data analysis technique. However, for time-series data, the very first check is that of 
stationarity. The Dickey-Fuller and Augmented Dickey-Fuller tests are employed here (see tables 1a and $1 b)$.

\begin{tabular}{|l|l|l|l|l|}
\hline Name of Variable & \multicolumn{2}{|l|}{ DF statistic at Level } & \multicolumn{2}{l|}{ DF statistic at First Difference } \\
\hline & Constant & $\begin{array}{l}\text { Constant and } \\
\text { trend }\end{array}$ & Constant & $\begin{array}{l}\text { Constant and } \\
\text { trend }\end{array}$ \\
\hline Total GDP Growth (TGG) & 0.20 & -2.24 & $-3.32^{* * *}$ & $-4.08^{* * *}$ \\
\hline Total Bank Credit (TBC) & 0.74 & -1.22 & $-3.81^{* * *}$ & $-4.24^{* * *}$ \\
\hline Bank Credit to Industry (BCI) & 3.05 & -0.89 & $-6.76^{* * *}$ & $-7.32^{* * *}$ \\
\hline
\end{tabular}

***, **, * indicates DF test value is significant at $1 \%, 5 \%$ and $10 \%$ level of significance respectively.

For constant model, critical values at $1 \%, 5 \%$ and $10 \%$ level of significance are, $-2.62,-1.95$ and -1.61 respectively

For constant and trend model, critical values at $1 \%, 5 \%$ and $10 \%$ level of significance are $-3.77,-3.19$ and -2.89 respectively

Table 1b: ADF Test of stationarity

\begin{tabular}{|l|l|l|l|l|}
\hline Name of Variable & \multicolumn{2}{|l|}{ ADF statistic at Level } & \multicolumn{2}{l|}{ ADF statistic at First Difference } \\
\hline & Constant & $\begin{array}{l}\text { Constant } \\
\text { and trend }\end{array}$ & $\begin{array}{l}\text { Constant } \\
\text { trend }\end{array}$ \\
\hline Total GDP Growth (TGG) & 0.19 & -2.29 & $-4.53^{* * *}$ & $-4.48^{* * *}$ \\
\hline Total Bank Credit (TBC) & 2.41 & 0.20 & $-3.83^{* * *}$ & $-4.15^{* *}$ \\
\hline Bank Credit to Industry (BCI) & 1.58 & -0.37 & $-6.70^{* * *}$ & $-7.23^{* * *}$ \\
\hline
\end{tabular}

$* * *, * * *$ indicates $\mathrm{ADF}$ test value is significant at $1 \%, 5 \%$ and $10 \%$ level of significance respectively

For constant model, critical values at $1 \%, 5 \%$ and $10 \%$ level of significance are, $-3.61,-2.94$ and -2.61 respectively

For constant and trend model, critical values at $1 \%, 5 \%$ and $10 \%$ level of significance are $-4.21,-3.53$ and -3.19 respectively

For the sake of brevity, we have named Total GDP Growth as TGG, Total Bank Credit as TBC and Bank Credit to Industry as BCI for the remainder of the text.

The tests of stationarity have to be performed for different possibilities, all of which have been included in the table. All three of our variables are not stationary at levels. This implies that we may need to test first differences for the same. If we run our analysis on level data, we are most likely to get meaningless or spurious results. Thus, we further perform the tests of stationarity at first differences. Now, all the calculated ADF values exceed the critical values. These indicate that all three variables are stationary at first differences and we can proceed to pair wise cointegration tests. We first begin with the cointegration between TGG and TBC. 


\section{3(a) Co-integration between TGG and TBC}

Selecting the appropriate lag length is crucial, as the test of co-integration is sensitive to lag lengths of the VAR system. We select the lag length that fulfils various criteria. In this case, it is 2 . This is shown in table 2 below.

Table 2: Lag Length Selection

\begin{tabular}{|l|l|l|l|l|l|l|}
\hline Lag & LogL & LR & FPE & AIC & SC & HQ \\
\hline 0 & -63.26 & NA & 0.11 & 3.43 & 3.52 & 3.46 \\
\hline 1 & 135.12 & 365.46 & 0.00 & -6.79 & $-6.54^{*}$ & -6.70 \\
\hline 2 & 142.29 & $12.45^{*}$ & $0.00^{*}$ & $-6.96^{*}$ & -6.53 & $-6.81^{*}$ \\
\hline 3 & 144.59 & 3.75 & 0.00 & -6.87 & -6.27 & -6.66 \\
\hline
\end{tabular}

* indicates lag order selected by the criterion; LR: sequential modified LR test statistic (each test at $5 \%$ level); FPE: Final prediction error AIC: Akaike information criterion; SC: Schwarz information criterion; HQ: Hannan-Quinn information criterion

Table 3: Statistics to check for cointegration

\begin{tabular}{|l|l|l|l|}
\hline Null & Alternate & Trace Statistic & Max-eigen Value Statistic \\
\hline $\mathrm{r}=0$ & $\mathrm{r}=1$ & $28.2(20.2)^{* * *}$ & $25.97(15.89)^{* * *}$ \\
\hline $\mathrm{r}<=1$ & $\mathrm{r}=2$ & $2.23(9.16)$ & $2.23(9.16)$ \\
\hline
\end{tabular}

Figure in parenthesis is critical value; $* * *$ denotes rejection of hypothesis at 0.01 level, $* *$ denotes rejection at 0.05 level

The results indicate that there exists one cointegrating vector. Both the criteria, i.e., the trace statistic and the max-eigen value statistic, indicate the presence of one cointegrating vector, and the pantula principle selects model 2, i.e., intercept in CE and no trend or intercept in VAR. This model selection is once again based on minimizing of certain criteria.

Table 4: Cointegrating Vector

\begin{tabular}{|l|l|l|l|}
\hline & TGG & TBC & C \\
\hline Coint. Vector & 1.00 & -1.85 & 5.67 \\
\hline
\end{tabular}

Normalized ECM: $\boldsymbol{T G G}=\mathbf{1 . 8 5 T B C} \boldsymbol{- 5 . 6 7}$

There is one cointegrating vector, and the TBC shows positive sign. This indicates a positive relationship between TBC and TGG.

\section{3(b) Co-integration between TGG and BCI}

Once again, selection of the appropriate VAR lag length is the first crucial step in the test of co-integration. We select the lag length that fulfils various criteria. We see that, once again, it is 2 . This is shown in table 5 below.

\section{Table 5: Lag Length Selection}

\begin{tabular}{|c|c|l|l|c|c|c|}
\hline Lag & \multicolumn{1}{|c|}{$\operatorname{LogL}$} & \multicolumn{1}{|c|}{ LR } & FPE & AIC & SC & HQ \\
\hline 0 & -56.19 & NA & 0.07 & 3.06 & 3.15 & 3.09 \\
\hline 1 & 115.56 & 316.39 & 0.00 & -5.77 & -5.51 & -5.67 \\
\hline 2 & 123.15 & $13.18^{*}$ & $0.00^{*}$ & $-5.96^{*}$ & $-5.52^{*}$ & $-5.80^{*}$ \\
\hline 3 & 124.64 & 2.43 & 0.00 & -5.82 & -5.22 & -5.61 \\
\hline
\end{tabular}

* indicates lag order selected by the criterion; LR: sequential modified LR test statistic (each test at 5\% level); FPE: Final prediction error; AIC: Akaike information criterion; SC: Schwarz information criterion; HQ: Hannan-Quinn information criterion

Next, we once again apply the pantula principle to test for cointegration.

\section{Table 6: Statistics to check for cointegration}

\begin{tabular}{|l|c|l|c|}
\hline Null & Alternate & Trace Statistic & Max-eigen Value Statistic \\
\hline $\mathrm{r}=0$ & $\mathrm{r}=1$ & $18.97(12.32)^{* * *}$ & $15.74(11.22)^{* * *}$ \\
\hline $\mathrm{r}<=1$ & $\mathrm{r}=2$ & $3.22(4.13)$ & $3.22(4.13)$ \\
\hline
\end{tabular}

Figure in parenthesis is critical value; *** denotes rejection of hypothesis at 0.01 level, ${ }^{* *}$ denotes rejection at 0.05 level

The results indicate that there exists one cointegrating vector. Both the criteria, i.e., the trace statistic and the max-eigen value statistic, indicate the presence of one cointegrating vector, and the pantula principle selects model 1, i.e., no intercept or trend or intercept in CE and VAR. This model selection is once again based on minimizing of certain criteria.

Table 7: Cointegrating Vector

\begin{tabular}{|l|l|l|}
\hline & TGG & BCI \\
\hline Coint. Vector & 1.00 & -1.76 \\
\hline
\end{tabular}

Normalized ECM: $T G G=1.76 B C I$

There is one cointegrating vector, and BCI shows positive sign. This once again indicates a positive relationship between $\mathrm{BCI}$ and $\mathrm{TGG}$. 


\section{3(c) Tests of Causality}

After checking for cointegration and error correction between our two sets of variables, we now check for causality between finance and growth, by running tests of granger causality (see table 8).

Table 8: Granger Causality Tests

\begin{tabular}{|l|l|l|l|l|l|}
\hline Null Hypothesis & Chi-sq & df & Prob. & F-statistic & Prob. \\
\hline TBC does not cause TGG & $12.56^{* * *}$ & 2 & 0.002 & $4.22^{* *}$ & 0.012 \\
\hline TGG does not cause TBC & 0.91 & 2 & 0.633 & 0.49 & 0.68 \\
\hline BCI does not cause TGG & 0.36 & 2 & 0.835 & 0.49 & 0.69 \\
\hline TGG does not cause BCI & $7.4^{* *}$ & 2 & 0.025 & 2.03 & 0.129 \\
\hline
\end{tabular}

*** denotes rejection of hypothesis at 0.01 level, ** denotes rejection at 0.05 level

The tests indicate that while TBC causes TGG, TGG doesn't cause TBC. This confirms the previous finding of unidirectional causality from TBC to TGG. However, we find that TGG causes BCI, but BCI doesn't cause TGG. This confirms the previous finding of unidirectional causality from TGG to BCI.

\section{Conclusion}

This study utilized forty years of Indian macroeconomic data, from 1972 to 2012, to analyze the causal relationship between Bank credit and GDP growth. The results are interesting, indicating unidirectional causality from total bank credit to economic growth; and from economic growth to bank credit to industry. This leads us to believe that financial availability, in the form of bank credit, does indeed lead to economic growth. Once there is economic growth, there is a further positive effect on provision of bank credit, especially to the industry.

In an economy that is growing rapidly and where there is a thriving industry, there will be further need of credit, especially in the manufacturing and industrial sectors. This particular trend has been observed from our analysis. Another important point to remember is that during periods of economic growth, most industries are looking to expand operations, for which they borrow money. During periods of slow economic growth, if banks and other financial institutions provide funds at attractive rates, it is bound to act as a catalyst to raise economic growth. Similarly, once adequate growth is achieved, it will lead to further expansion of the banking sector itself, and lead to a greater availability of industrial credit. There will also be a more diverse range of financial instruments and arrangements that crop up to meet the increased demand for credit.

\section{References}

- $\quad$ Acharya D, S Amanulla and S Joy, (2009), "Financial Development and Economic Growth in Indian States: An Examination", International Research Journal of Finance and Economics, Issue 24.

- Bell, C and PL Rousseau (2001), "Postindependence India: a case of finance-led Industrialization?" Journal of Development Economics, 65, 153-175.

- Blackburn, K, Bose, N, and S Capasso, (2005), "Financial development, financing Choice and economic growth", Review of Development Economics, 9, 135-149.

- Boyd, JH and EC Prescott, (1986), "Financial intermediary-coalitions", 
Journal of Economic Theory, 38, 211-232.

- Boyd, JH and BD Smith (1998), “The evolution of debt and equity market in Economic development", Economic Theory 12, 519-560.

- Chakraborty, I, (2007), "Does Financial Development Cause Economic Growth? The case of India", Occasional Paper 9, Institute of Development Studies, Kolkata.

- Chakraborty, I, (2010), “Financial Development and Economic Growth in India: An analysis of the post reform period", South Asia Economic Journal, $11: 287$.

- Chakraborty, I and S Ghosh, (2011), “The relationship between Financial Development and Economic growth and the Asian financial crisis: An FMOLS analysis", International Journal of Economic Research, 2(3): 88-101.

- $\quad$ Demetriades, PO, and KA Hussein, (1996), "Does Financial Development Cause Economic Growth? Time-Series Evidence from 16 Countries" Journal of Development Economics 51 (Dec. 1996): 387-411.

- Greenwood, J, and B Jovanovic (1990), "Financial Development, Growth, and the Distribution of Income", Journal of Political Economy 98 (Oct. 1990): 1076-1107.

- $\quad$ Jung, WS (1986), "Financial Development and Economic Growth: International Evidence", Economic Development and Cultural Change, 34: 333-346.

- $\quad$ King, RG, and R Levine (1993), "Finance and Growth: Schumpeter Might Be Right", Quarterly Journal of Economics 108 (Aug. 1993): 717-738.
Neusser, K, and M Kugler (1998), "Manufacturing Growth and Financial Development: Evidence from OECD Countries" Review of Economics and Statistics 80 (Nov. 1998): 638-646.

Pagano, M (1993), "Financial Markets and Growth: An overview", European Economic Review, 37, 613-622.

Pradhan, RP, (2010a), "The Nexus between Finance, Growth and Poverty in India: The Cointegration and Causality Approach", Asian Social Science Vol. 6, No. 9

Pradhan, RP, (2010b), "Financial Deepening, Foreign Direct Investment and Economic Growth: Are They Cointegrated", International Journal of Financial Research Vol. 1, No. 1; December 2010.

Pradhan, RP, (2011), "Financial Development, Growth and Stock Market development: The Trilateral Analysis in India”, Journal of Quantitative Economics, Vol. 9 No. (1).

- Rousseau, PL, and R Sylla, (2005), "Emerging Financial Markets and Early U.S. Growth", Explorations in Economic History 42 (Jan. 2005): 1-16. 